\title{
University education and national minorities in South Tyrol
}

\author{
doc. Dr. iur. Harald Christian SCHEU, Mag. phil., Ph.D.
}

\begin{abstract}
For a long time, university education for national minorities has been a blind spot in minority research. The situation of university education in South Tyrol seems to be an exception, because in South Tyrol the question of higher education, for many years, has been the subject of intensive political and academic discussion. This discussion may be seen as paradigmatic since it includes both the concept of ethnic segregation and the concept of universality. In this paper, we focus on the legal basis and the praxis of university education in South Tyrol which is a compromise between ethnic segregation and multicultural universality. In recent years, the Free University of Bozen has become a symbol for overcoming segregation and it opened a new perspective to the members of the two major language groups in South Tyrol.
\end{abstract}

\section{Keywords}

autonomy, education, Italy, South Tyrol, university

\section{Introduction}

For a long time, university education for national minorities has been a blind spot in minority research. In 2012, Xabier Arzoz, professor of constitutional and administrative law at the University of Bilbao, ${ }^{1}$ wrote that no problem of language policy was paid as little attention to as the issue of university education for national minorities. According to Arzoz, there was no single monograph that systematically investigated the importance of university education in minority languages for the reproduction of linguistic minorities. Even in countries that were officially bilingual or multilingual, there was a lack of systematic studies on bilingual university education. ${ }^{2}$

1 Universidad del País Vasco / Euskal Herriko Unibertsitatea.

2 ARZOZ, Xabier: Legal education in bilingual contexts: a conceptual, historical and comparative introduction, in: Bilingual higher education in legal context: Group Rights, State Policies and Globalisation, ARZOZ, Xabier (ed.) Leiden 2012, 3-34. 
The situation of university education in South Tyrol, i.e. a political entity claiming equal use of Italian and German language in different fields of social life, ${ }^{3}$ seems to be an exception. In South Tyrol, the question of higher education, for many years, has been the subject of intensive political and academic discussion. This discussion may be seen as paradigmatic since it includes both the concept of ethnic segregation and the concept of universality. The German-speaking minority traditionally understands ethnic segregation as a means of preserving a distinct minority identity. The concept of university, on the other hand, refers to an open and multicultural institution.

In this paper, we want to briefly outline the legal basis and the current form of university education in South Tyrol, taking into account the specific characteristics of higher education in the wider context of South Tyrol's minority education system. The aim of the paper is to present and evaluate the South Tyrolean compromise between ethnic segregation and multicultural universality.

\section{The historical heritage of language policy in South Tyrol}

In South Tyrol, the system of primary and secondary education is based on the concept of ethnic and linguistic segregation. The current state reflects the negative historical experience of the German-speaking minority with the policy of assimilation and Italianization that the fascist government of Italy carried out in the interwar period. ${ }^{4}$ Fascist measures directed against the use of the German language before the state authorities and against education in German language have left lasting traces in the collective memory of the German-speaking minority. ${ }^{5}$ After the Paris Agreement of 5 September 1946 had established some principles of territorial autonomy for the provinces of Bozen (South Tyrol) and Trento (Trentino), the political representation of the German national minority focused on preventing the influence of Italian culture on the education of German-speaking pupils and against any mixing of the German language with other languages within the education system. ${ }^{6}$

Article 19 of the 1972 Statute of Autonomy ${ }^{7}$ presupposes systematic segregation according to membership in a particular language group. The administration of Italian schools in South Tyrol is in the hands of an official appointed by the Italian Ministry of Education

3 Cf. Article 1 (b) of the Agreement between the Italian and Austrian Governments of 5 September 1946. As the Agreement was signed by the then Italian Foreign Minister Alcide de Gasperi and Austrian Foreign Minister Karel Gruber, it is sometimes referred to in professional literature as the Gruber-De Gaspari Agreement. Also the term "Paris Agreement" is used because it was signed at the Paris Conference. The autonomy provided under the Agreement has been implemented on the basis of the Statute of Autonomy of 1972.

4 On the consequences of Italian fascism on the situation in South Tyrol, see GRUBER, Alfons: Südtirol unter dem Faschismus, Bozen 1978.

5 On some effects of Italianization, see SCHEU, Harald Christian: Úprava dvojjazyčných topografických označení v Jižním Tyrolsku, in: Acta Universitatis Carolinae luridica, 2015, 4, 125-134.

6 BAUR, Siegfried: Schulpolitik in Südtirol, in: Die Verfassung der Südtiroler Autonomie: die Sonderrechtsordnung der Autonomen Provinz Bozen/Südtirol, MARKO, Joseph et al. (eds.), Baden-Baden 2005, 351-366.

7 See the Decree of the President of the Republic No. 670 of 31 August 1972, No. 670 authorising of the standardised text of constitutional laws concerning the special arrangements for Trentino-Alto Adige. 
after hearing the South Tyrolean provincial government. An official appointed by the South Tyrolean provincial government after hearing the Italian Ministry of Education is responsible for the administration of German schools. ${ }^{8}$ As a result of this dichotomy, there have been set up German schools in which all teaching takes place in German language and Italian schools where all classes are held in Italian language. Teaching is provided by teachers for whom the language is a native language. The teaching of the second language, i.e. the teaching of Italian language at German schools and of German language at Italian schools, is compulsory, but as part of a special subject. In practice that means that Italian pupils study German as a foreign language, similarly as German pupils study Italian language. ${ }^{9}$ The basic philosophy of ethnic segregation has been probably best expressed by Anton Zelger ${ }^{10}$ when he said: "The better we separate from each other, the better we understand each other". ${ }^{11}$ Therefore even today, the German-speaking minority considers any attempt to soften the rigid language segregation as very problematic. At present, the struggle of the German-speaking minority for cultural identity is directed against the concept of socalled immersion that came from Canada to Europe and is practiced in a number of schools, for example, in Finland and Germany. The characteristic feature of immersion is the use of the second language in different learning situations. ${ }^{12}$ Such departure from the segregation model is perceived as a potential threat to the cultural and ethnic identity of South Tyrol. ${ }^{13}$

The model of ethnically segregated education is certainly not in line with the knowledge and methods of modern science. The great intercultural potential of South Tyrol is far from being exhausted under the current education system. However, in recent years, various innovative projects have been introduced in order to improve the knowledge of the second language at South Tyrolean schools. Law No. 5 of 16 July 2008 provides schools with some space for applying their own methodologies of language education, which must, however, be compatible with the above-mentioned provision of Article 19 of the Statute of Autonomy. ${ }^{14}$

8 See Article 10 para. 4 and 5 of the Statute of Autonomy.

9 On the complex question of who belongs to the German or Italian language group in South Tyrol, see SCHEU, Harald Christian: Používání menšinových jazyků ve styku se správními orgány a soudy v Jižním Tyrolsku, in: Acta Universitatis Carolinae luridica, 2015, 4, 87-97.

10 Between 1969 and 1989, Anton Zelger held the post of minister (Landesrat) for German-language education and culture in the provincial government. In line with the logic of the system another member of the provincial government is responsible for Italian language education and culture. In the current provincial government, Christian Tommasini for the Italian language group and Philipp Achammer for the German language group hold those positions.

11 "Je besser wir trennen, desto besser verstehen wir uns". Quoted from WOELK, Jens: Forschung und Lehre in Südtirol, in: Die Verfassung der Südtiroler Autonomie: die Sonderrechtsordnung der Autonomen Provinz Bozen/ Südtirol, MARKO, Joseph et al. (eds.), Baden-Baden 2005, 435-448.

12 On the concept of immersion, see ANDRÁŠOVÁ, Hana: Mnohojazyčnost v podmínkách českého školství se zřetelem na výuku němčiny a angličtiny, Brno 2012, 17-19.

13 STEININGER, Rolf: Südtirol im 20. Jahrhundert: vom Leben und Überleben einer Minderheit, Innsbruck 2004.

14 See MERANER, Rudolf: Südtirol - Paradies zum Sprachenlernen?, in: Erziehung und Unterricht, 2011, 1-2, $162-171$. 


\section{The situation of university education for South Tyrol}

Given that the concept of ethnic segregation penetrates the whole school system in South Tyrol, it was difficult to get support for the idea of a university in the capital of Bozen. However, we shall not overlook other relevant factors. South Tyrol is a predominantly mountainous and agrarian region, where only $5 \%$ of the population has a university diploma. The towns of South Tyrol, which until 1919 were part of the united Tyrol, did not constitute centers of regional administration or education during the period of the monarchy. By the time of the annexation of the area by Italy, the southern part of Tyrol perceived Innsbruck as the natural capital and its university as the center of higher education. ${ }^{15}$

Still in the first half of the 1990s, higher education for South Tyrolean students was provided exclusively outside the Autonomous Province of Bozen. In 1993/94, a total of 10,524 South Tyrolean students were enrolled, of which 5,430 at Italian universities and 5,094 at foreign universities. The University of Trento $(2,060$ enrolled students) was dominant among Italian universities, the University of Innsbruck (3,544 registered students from South Tyrol) among foreign universities. ${ }^{16}$ According to Jens Woelk, who has been working for many years at the European College in Bozen and has been teaching at the University of Trento since 2010, the University of Innsbruck is still perceived as the true Tyrolean university ("Landesuniversität") for the German-speaking population of South Tyrol. The University of Trento, founded in 1962, is a relatively young university, but has the reputation of being one of the best universities in Italy. ${ }^{17}$

\section{The development after the Second World War}

The above-mentioned statistics reflect the traditional rivalry of Italy and Austria for the influence on South Tyrolean students' higher education. From the Austrian perspective, university education is an area in which the kin-state ${ }^{18}$ can very actively support a related minority abroad. Studies at Austrian universities provided South Tyrolean students a highquality education. On the other hand, however, the support of the kin-state has delayed South Tyrolean efforts to establish its own university education within the autonomous province of Bozen.

Even after the end of the fascist regime in Italy, the political situation was not much in favor of the establishment of a South Tyrolean university. Under Article 3 (b) of the Paris Agreement of 1946, the Italian Government undertook to conclude a bilateral agreement on the mutual recognition of university diplomas. The implementation of this commitment,

\footnotetext{
15 WOELK, 436.
}

16 lbidem, 437-438.

17 Ibidem, 438.

18 On the role of the kin-state in the field of national minority protection, see SCHEU, Harald Christian: Postavení „mateřské země" a př́buzné menšiny z hlediska mezinárodní ochrany lidských práv, in: Acta Universitatis Carolinae luridica, 2015, 4, 169-182. 
however, encountered major obstacles. Only in 1950, a regulation for the recognition of foreign university diplomas was adopted, but only for the benefit of those South Tyroleans who had opted for Germany during the fascist period and returned to their homes after the Second World War. ${ }^{19}$ Italy recognized diplomas in the fields of medicine, technology and science. With regard to other disciplines, the Italian regulation foresaw a complicated, lengthy and costly validation procedure which was carried out by Italian universities outside of South Tyrol. ${ }^{20}$

The establishment of a summer school in Brixen, which starting in 1952 was operated by the University of Padua, caused quite a stir. The summer courses were mainly attended by students from other parts of Italy. While the leadership of the University of Padua conceived the Brixen summer school as a sign of the intellectual dominance of Italian culture, the South Tyrolean political elite spoke of a new way of colonization. Germanspeaking politicians therefore demonstratively boycotted all representative events related to the summer school. ${ }^{21}$

South Tyrol's political leadership with the support of Austria further negotiated with the Italian government on the recognition of Austrian university diplomas. In 1956, mutual recognition of diplomas was extended to the fields of philosophy, psychology, history and philology. However, in particular, the education of secondary school teachers remained problematic. When the South Tyrolean parliament ("Landtag") decided to grant special scholarships for South Tyrolean students studying in German-speaking countries, this act was vetoed by the Italian government. The recognition of Austrian diplomas was met with little enthusiasm on the part of Italian universities. In 1956, the Rector of University of Milan, Giuseppe De Francesco, said during a debate in the Italian Parliament that it was possible to recognize diplomas issued by the University of Vienna but that diplomas obtained at the University of Innsbruck could hardly be seen as equivalent to those of Italian universities. ${ }^{22}$

In this situation, it was the neo-fascist party which began to think about the founding of a university for South Tyrol. According to the neo-fascists, such regional university would outweigh the great influence of the University of Innsbruck, which by some Italian politicians was called the center of Tyrolian irredentism..$^{23}$ It is not surprising that, under such circumstances, representatives of the German language group were clearly opposed

19 According to the Italian-German agreement on the resettlement of the South Tyrolean population, which was concluded in June 1939, persons opting for German citizenship had to move to Germany. Members of the German-speaking minority who decided to stay in South Tyrol were no longer entitled to preserve their own culture and their own language. The inhabitants of South Tyrol had to decide on their option by 31 December 1939. During this period, according to official statistics, over 166,000 members of the German-speaking minority chose German citizenship, 63,000 members decided to remain in South Tyrol.

20 PETERLINI, Hans Karl: Das trojanische Pferd. Wurzeln der Universitätsfeindlichkeit in Südtirol, in: Universitas est. Essays und Dokumente zur Bildungsgeschichte in Tirol/Südtirol, PETERLINI, Hans Karl - OBERMAIR, Hannes (eds.), Bozen 2008, 162-188.

21 lbidem, 173.

22 Ibidem, 179.

23 Ibidem, 179-181. 
to the idea of a South Tyrolean university, since they assumed that the planned university would be conceived as a branch of an Italian university and would primarily serve the interests of the Italian language group. In 1972, the political leadership of South Tyrol made a clear decision that there should be no university in South Tyrol. The project of a university was referred to as a Trojan horse and as a bridgehead for Italianization. Germanspeaking politicians were afraid of the arrival of a large number of students from other Italian provinces to Bozen. ${ }^{24}$

\section{The establishment of the Free University of Bozen}

After a very dramatic development in the 1960s, the situation in South Tyrol was gradually stabilized on the basis of the new statute of autonomy adopted in 1972. The new statute was followed by dozens of legislative measures which were conceived with a view to ensuring bilingualism in various areas of public life. ${ }^{25}$ The Decree of the President of the Republic No. 574 of 1988 was one of the central implementing regulations as it provided for the equality of German and Italian language in all areas of public administration (except the military) and the judiciary. Due to the composition of the population, ${ }^{26}$ German language again became the dominant language for South Tyrol. The successful implementation of the Statute of Autonomy was also reflected in the bilateral relations between Italy and Austria when, in 1992, Austria officially notified the Italian government that it considered the dispute over the implementation of the 1946 Paris Agreement to be terminated.

The change in the political situation may be seen as one of the impetus for the resumption of the debate on university education in South Tyrol. Besides that, new approaches towards the organization of higher education after 1990 played an important role. In many European countries, universities were granted a greater degree of autonomy, and the organization of the study programs was decentralized. ${ }^{27}$ In Italy, in particular, the parliament adopted Act No. 341/1990, according to which teachers in nursery schools and elementary schools needed to have a university degree (so-called legge Ruberti). Like other Italian regions, South Tyrol had to deal with this requirement. ${ }^{28}$

So, it became clear that the new concept of university education called for a certain change of attitude. However, due to the continuing resistance against the founding of a South Tyrolean university, a compromise was reached in 1992. Relevant actors agreed to set up the so-called European Academy, which was conceived as an academic research institute

\section{WOELK, 439.}

25 BAUR, 358.

26 According to the 2011 census, members of the German language group made up almost $70 \%$ of the population, the Italian language group over $25 \%$. The Ladin language group constituted $4.5 \%$ of the South Tyrolean population.

27 See e.g. the Austrian University Organisation Act (Universitätsorganisationsgesetz) of 1993.

28 EBERHÖFER, Andrea: Die Entwicklung der in Südtirol eingesetzten Schulbücher von 1919 bis in die 1960er Jahre: inhaltliche Transformationsprozesse in den Fibeln, Augsburg 2009, 65. 
based in Bozen. ${ }^{29}$ Formally, the Academy was a privately owned non-profit organization, but the Autonomous Province of Bozen became its majority owner. ${ }^{30}$

Under Article 3 para. 4 of its founding statute, the European Academy shall focus on research in four major areas: firstly the Alpine environment, secondly health, thirdly technology, and, fourthly languages, minorities and autonomy. According to Article 4 of the statute, the European Academy shall take into account the needs of linguistic minorities in South Tyrol so that the three language groups (Italian, German and Ladin) will be adequately represented in the bodies of the Academy. ${ }^{31}$ In practice, research conducted by the European Academy is based on interdisciplinarity and multilingualism, and communication in the Academy takes place without translation.

Not only has the European Academy removed psychological barriers on the part of Germanspeaking politicians, but even more, the Academy set up a working group which actively promoted the idea of a university. A final study presented by the Academy's working group in 1994 became an important impetus. Already in January 1995, the Land Government decided to draw up a university project for South Tyrol, which was completed in December 1995 and subsequently submitted to the Italian Ministry of Education. The provincial government attached great importance to the fact that a new university in Bozen would not weaken the role of the universities in Innsbruck and Trento. In particular, it refused to transfer legal education from Innsbruck ${ }^{32}$ to Bozen. ${ }^{33}$

The choice of the proper legal form of the new university was a very complex task. If the University in Bozen was to be established as a branch of the University in Innsbruck, that would require a change in the bilateral Austro-Italian treaty. On the other hand, if the University in Bozen was conceived as an Italian state university, this would make the appointment of foreign professors very complicated. It was also very unlikely that the competent Italian bodies of central administration would transfer their powers to the autonomous authorities in Bozen to enable them the establishment of a public university in South Tyrol. For these reasons, the form of a so-called free university was finally chosen. This choice was made with regard to Italian law no. 127/1997 (legge Bassanini-bis), which introduced further decentralization in the field of university education. ${ }^{34}$

\section{WOELK, 440.}

30 The legal basis for the participation of South Tyrol in the European Academy was Provincial Law No. 31 of 29 October 1991.

31 The current version of the founding Statute is available on the European Academy website, online: http:// www.eurac.edu/de/aboutus/organisation/bylaws/Pages/default.aspx.

32 At the University of Innsbruck, an integrated curriculum on Italian law is being provided in cooperation with the University of Padova. The program offers bilingual teaching of Italian law during four years of study. The training of South Tyrolean lawyers in Innsbruck is still considered to be a cornerstone of the common Tyrolean identity. See ALBER, Elisabeth - PALERMO, Francesco: Creating, studying and experimenting with bilingual law in South Tyrol. Lost in Interpretation?, in: Bilingual higher education in legal context: Group Rights, State Policies and Globalisation, ARZOZ, Xabier (ed.), Leiden 2012, 287-309.

33 See WOELK, 441-442.

34 On the scope of the reform, see HÖLLRIGL, Peter - MERANER, Rudolf - PROMBERGER, Kurt (eds.): Schulreformen in Italien und ihre Umsetzung in Südtirol, Innsbruck 2005. 
Under Article 17 para. 120 of Law No. 127/1997, the autonomous provinces of Bozen (South Tyrol) and Valle d'Aosta gained the right to establish a non-state university on their territories. Academic degrees provided by those universities are to be recognized by the competent Italian authority. Article 17 para. 121 of the cited law transferred to South Tyrol all powers related to the financing of the university and the possible expropriation of buildings for the purpose of operating the university. However, powers related to the approval of the study regulations remained with the central authorities in Rome. Interestingly, Article 17 para. 122 of the law expressly stipulates that the University of Trento and the universities in South Tyrol and Valle d'Aosta shall cooperate with academic and research institutions in EU Member States.

The Free University of Bozen was founded in October 1997 on the basis of a notarial record initiated by a private-law association. Despite the formal private-law status, however, the University of Bozen is financed almost exclusively from public sources, from both the province of Bozen and the Italian state. For administrative staff, bilingualism is expected, which is typical for the public domain in South Tyrol. According to Jens Woelk, therefore, the choice of a private-law form instead of a public-law form does not have any important effect in practice. ${ }^{35}$

The Free University in Bozen boasts of its multilingualism and interculturalism. Unlike administrative staff, university teachers do not need to have knowledge of Italian and German. Almost 30 \% of teachers come from abroad. In 1998, two faculties, the Faculty of Economics in Bozen and the Faculty of Education in Brixen, began to operate at the University. The Faculty of Education, offering courses in German and Italian, focuses on the preparation of teachers of elementary and nursery schools. The Faculty of Economics offers programs related to agriculture and tourism. In the following years, faculties for natural sciences, for informatics and for design also came into being. As a rule, lectures at those faculties are held in three languages, i.e. in Italian, German and English.

\section{Concluding considerations}

For the protection of linguistic minorities and their languages it is essential that members of the minority have the opportunity to use their language in various social situations. The use of a minority language within university education can be important in the context of consolidation and further development of the minority language. At the same time, university-educated members of the minority contribute to the prestige of the minority language and the entire community. Particularly in South Tyrol, where the official statistics show a comparatively very low share of academics, the second aspect seems very relevant. It is therefore somewhat paradoxical that the political representation of the Germanspeaking minority, which forms a large majority in the autonomous province itself, has long been opposed to the idea of establishing a university in Bozen. The protection of minorities in South Tyrol is governed by the 1972 Statute on Autonomy, which is based on the philosophy of linguistic and ethnic segregation. The German-speaking minority, which, 
after the annexation of South Tyrol by Italy and during the fascist regime, was subjected to assimilation measures and sometimes even to brutal persecution, voluntarily opted for this segregation as it considered it the best guarantee of its own cultural and linguistic identity. A university which serves as a symbol of another model of language policy, therefore, clearly went beyond the Statute of Autonomy.

From the perspective of minority protection, the contribution of the Free University of Bozen can be evaluated quite positively. Obviously, there was no new paradigm introduced into the concept of language protection in South Tyrol. There was no change in the statute of South Tyrol's autonomy. The original concerns about potential migration of Italian students to South Tyrol have proven to be unfounded. Indeed, the Free University has a considerable number of students coming from Germany. The traditional ties between South Tyrol and Austria have not been weakened, as the University of Innsbruck has remained one of the centers of higher education for South Tyrolean students. The Free University of Bozen has built its reputation as a good and successful academic institution without compromising the fragile balance of language policy in South Tyrol.

The Free University, which is a symbol for overcoming segregation, opened a new perspective to the members of the two major language groups in South Tyrol. Minority language is not only a distinguishing feature of a particular minority identity and a medium for its rich culture, although this aspect is still very important. Besides that, the knowledge of languages and their use in the higher education process is also a challenge for individual minority members and enables them to transcend ethnic boundaries, both for their own benefit and ultimately for the benefit of the entire language group.

\section{References}

ALBER, Elisabeth - PALERMO, Francesco: Creating, studying and experimenting with bilingual law in South Tyrol. Lost in Interpretation?, in: Bilingual higher education in legal context: Group Rights, State Policies and Globalisation, ARZOZ, Xabier (ed.), Leiden 2012, 287-309.

ANDRÁŠOVÁ, Hana: Mnohojazyčnost v podmínkách českého školství se zřetelem na výuku němčiny a angličtiny, Brno 2012.

ARZOZ, Xabier: Legal education in bilingual contexts: a conceptual, historical and comparative introduction, in: Bilingual higher education in legal context: Group Rights, State Policies and Globalisation, ARZOZ, Xabier (ed.), Leiden 2012, 3-34.

BAUR, Siegfried: Schulpolitik in Südtirol, in: Die Verfassung der Südtiroler Autonomie: die Sonderrechtsordnung der Autonomen Provinz Bozen/Südtirol, MARKO, Joseph et al. (eds.), Baden-Baden 2005, 351-366.

EBERHÖFER, Andrea: Die Entwicklung der in Südtirol eingesetzten Schulbücher von 1919 bis in die 1960er Jahre: inhaltliche Transformationsprozesse in den Fibeln, Augsburg 2009.

GRUBER, Alfons: Südtirol unter dem Faschismus, Bozen 1978.

HÖLLRIGL, Peter - MERANER, Rudolf-PROMBERGER, Kurt (eds.): Schulreformen in Italien und ihre Umsetzung in Südtirol, Innsbruck 2005. 
MERANER, Rudolf: Südtirol - Paradies zum Sprachenlernen?, in: Erziehung und Unterricht, 2011, 1-2, 162-171.

PETERLINI, Hans Karl: Das trojanische Pferd. Wurzeln der Universitätsfeindlichkeit in Südtirol, in: Universitas est. Essays und Dokumente zur Bildungsgeschichte in Tirol/ Südtirol, PETERLINI, Hans Karl - OBERMAIR, Hannes (eds.), Bozen 2008, 162-188.

Satzung, online: http://www.eurac.edu/de/aboutus/organisation/bylaws/Pages/default. aspx.

SCHEU, Harald Christian: Postavení "mateřské země" a príbuzné menšiny z hlediska mezinárodní ochrany lidských práv, in: Acta Universitatis Carolinae luridica, 2015, 4, 169-182.

SCHEU, Harald Christian: Používání menšinových jazyků ve styku se správními orgány a soudy v Jižním Tyrolsku, in: Acta Universitatis Carolinae luridica, 2015, 4, 87-97.

SCHEU, Harald Christian: Úprava dvojjazyčných topografických označení v Jižním Tyrolsku, in: Acta Universitatis Carolinae luridica, 2015, 4, 125-134.

STEININGER, Rolf: Südtirol im 20. Jahrhundert: vom Leben und Überleben einer Minderheit, Innsbruck 2004.

WOELK, Jens: Forschung und Lehre in Südtirol, in: Die Verfassung der Südtiroler Autonomie: die Sonderrechtsordnung der Autonomen Provinz Bozen/Südtirol, MARKO, Joseph et al. (eds.), Baden-Baden 2005, 435-448.

\section{Author}

doc. Dr. iur. Harald Christian Scheu, Mag. phil., Ph.D.

Právnická fakulta, Univerzita Karlova

Faculty of Law, Charles University

nám. Curieových 901/7, 11640 Praha 1, Czech Republic

scheu@prf.cuni.cz 